\title{
1. On the Anatomy of Aramus scolopaceus.
}

By A. H. Garrod, M.A., F.Z.S., Prosector to the Society.

[Received February 7, 1876.]

It being very seldom that an opportunity occurs for the study of the anatomy of Aramus, a form the exact relations of which are but little understood, I take the opportunity of describing this bird from a female specimen which reached the Society's Gardens alive, and died, much emaciated, within a few days, on Oct. 7, 1875. I may mention that the generic name Scolopax was applied to it by Linnæus, and that Lichtenstein termed it Rallus gigas. Mr. G. R. Gray* places it among the Rallinæ, next to Rallus aquaticus, whilst Messrs. Sclater and Salvin $\uparrow$ include it among the Alectorides, together with Eurypyga, Cariama, and Psophia. It seems to me, however, that, considering its different anatomical features, it is most intimately related to Grus, which, with it, is not distant from Ibis, Platalea, and Eurypyga.

With reference to the skeleton of Aramus, it may be mentioned that it is figured as a whole in Eyton's 'Osteologia Avium' (pl. xiv. $\mathrm{K}$ ), and in the same valuable work (pl. 27. fig. 2) a front view of the sternum, and a back view of the pelvis are given, though the plate is incorrectly lettered.

In Audubon's 'Ornithological Biography' $\ddagger$ a full account of the viscera is given, with a woodcut of the alimentary canal. The author considers the bird to be most intimately allied to the Rails.

Aramus is a strongly schizorhinal bird $\S ;$ in other words, the openings of the external osseous nares extend further backwards than the posterior ends of the nasal processes of the præmaxillæ. In this respect it agrees with Grus, Eurypyga, and the Limicolæ, but not with the Rallidæ, nor with Cariama, nor with Psophia.

As in Grus, Ibis, and Platalea, the lachrymal bones do not blend with the region of the skull where they are attached; in the true Limicolæ they do so. The palate is schizognathous, the maxillopalatines long, the vomer pointed, and the pterygoids out-spreading at both ends exactly as in Grus. As in that genus, also, there is a pair of occipital foramina, like those in Ibis, Platalea, and the Limicolæ; but these do not occur in the Rallidæ, nor in Cariama, nor in Psophia. (Figs. 1, 2, and 3, p. 276, illustrate these points.)

The sternum is completely Gruine, as are the other parts of its skeleton.

The pterylosis of Aramus has been fully investigated by Nitzsch \|, who found that it agrees exactly with that of Psophia and Grus, and with no other bird. The peculiarities of the feathers themselves led that illustrious naturalist to place it with the Rails, from which it differs in more than one pterylographic particular.

* Hand-list of Birds, vol. iii. p. 58.

+ Nomenclator Avium Neotropicalium, p. 141.

† Vol. iv. p. 547 et seq. \$ Vide P. Z. S. 1873, p. 33.

* Ray Society's English Translation, p. 125. 
There are two carotid arteries; and the right jugular vein, as is frequently the case, is considerably the larger of the two.

The trachea is simple (the specimen is a female); the syrinx is somewhat dilated; and a single pair of intrinsic muscles is continued to the bronchial half-ring.
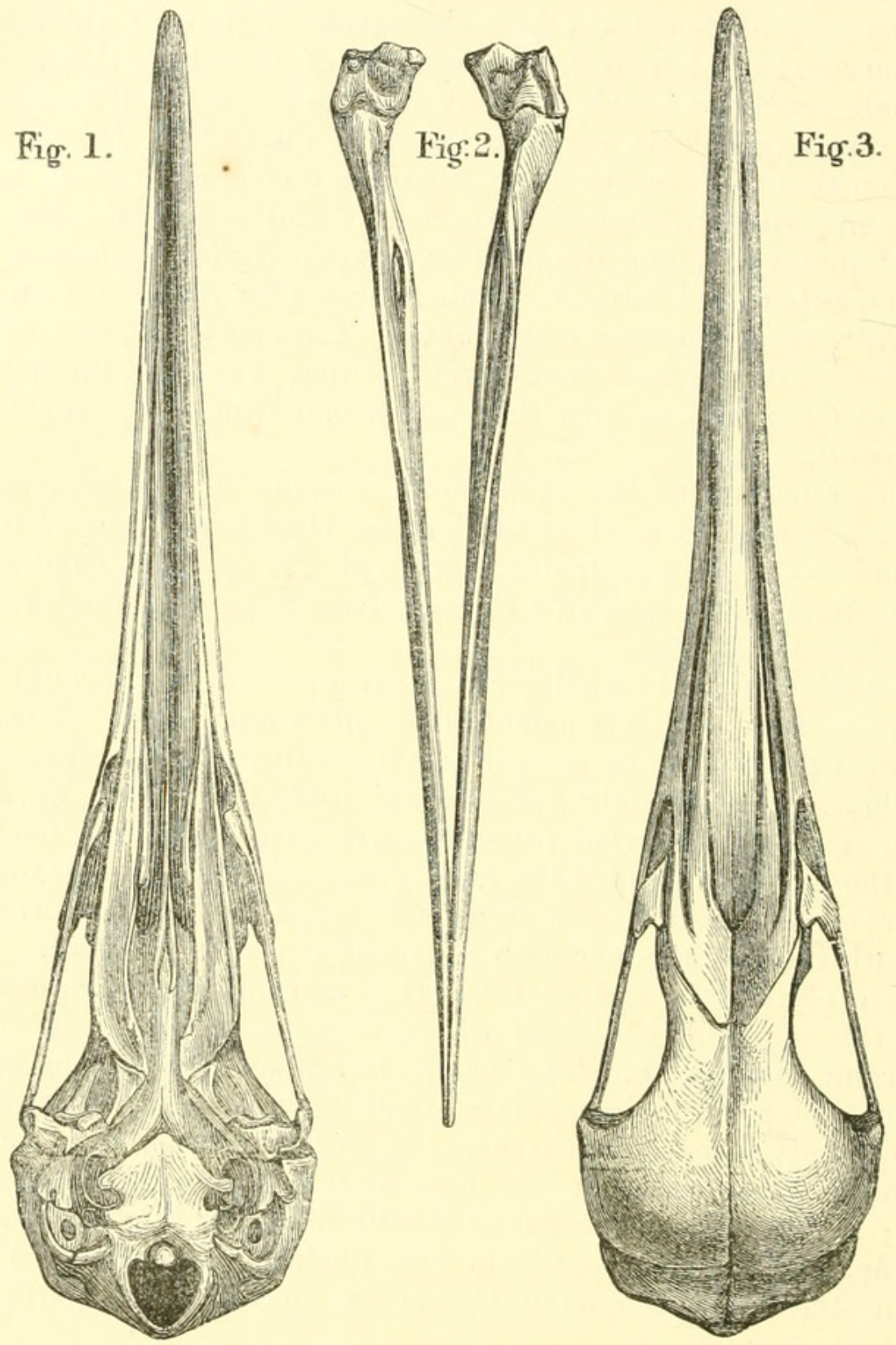

Fig. 1. Skull of Aramus scolopaceus, palatal view.
2. Ditto
ditto
Jower jaw.
3. Ditto
ditto
top view.

Myologically, the ambiens muscle is strong; the femoro-caudal (A) is absent, the accessory femoro-caudal (B) is thin and small; the semitendinosus (X) and the accessory semitendinosus (Y) are fairly developed. Its muscle-formula * is therefore B,XY. In all the Rallidæ the formula is $\mathrm{AB}, \mathrm{XY}$, the femoro-caudal being large. In

* Vide P. Z. S. 1874, p. 111. 
Psophia it is B,XY, as it is in Cariama (in Chunga B is also absent). In Balearica regulorum the formula is XY; in Grus antigone it is $\mathrm{AB}, \mathrm{XY}$, the femoro-caudal being reduced to almost a thread; in Anthropoides virgo the formula is AB,XY, as it is in Ibis and Platalea, as well as in Eurypyga. Myology therefore does not militate against the Gruine affinities of Aramus.

Further, as in Grus, the tensor fascia covers the biceps cruris; the biceps humeri muscle sends a special belly into the patagium; the expansor secundariorum is Ciconine; the obturator internus has a triangular origin*.

Alimentary canal.-The tongue is $2 \frac{1}{2}$ inches long, very slender, quite smooth, nearly cylindrical, and tapering to a fine point in front. It has a slight papillary fringing at its posterior edge. The oesopha$g u s$ is very capacious, although no crop is developed. The proventriculus is zonary ; its glands are cylindrical and short. Between it and the gizzard is a capacious dilatation of the termination of the gullet, lined, apparently, with squamous epithelium, the volume of which is greater than that of the interior of the gizzard itself. The gizzard is not large, and its muscular walls are not thick. The liver has the left lobe a little larger than the right, a condition far from common among birds; the gall-bladder is present. The averagesized, or slightly narrow, intestines are 40 inches in length. The caca are somewhat dilated toward their blind ends; they are 2 and $2 \frac{1}{4}$ inches long. They are peculiar in being situated laterally, and close together, instead of opposite one another, a condition approximated to in most of the non-columbine Schizorhinal birds, and in them only; the small intestine therefore enters the colon by a lateral, slit-like opening. In the Cranes the cæca are generally between 5 and 6 inches long; and they being so much larger, the comparative size is much the same. In Ibis, Platulea, and Eurypyga they are very much shorter; in Cariama they measure 10 inches, whilst in Psophia their length is much the same as in Aramus.

2. On the past and present Geographical Distribution of the Large Mammals of South Africa. By T. E. Buckley, B.A., F.Z.S.

[Received February 7, 1876.]

After I had made arrangements for an expedition to South Africa, principally for the purpose of sport, in 1873, the University of Cambridge offered me a grant from the "Wort's Fund," on the condition that I should send home a collection of specimens equal in value to the amount of the grant, and should also make a report to the Vice-Chancellor, detailing any observations that I thought of sufficient importance to be preserved.

As the larger Mammals are yearly receding further into the interior, and as their total extinction is only a question of time, I thought $I$

* For further reference to these points, vide P. Z. S. 1876, p. 195. 


\section{$2 \mathrm{BHL}$ Biodiversity Heritage Library}

Garrod, A. H. 1876. "1. On the Anatomy of Aramus scolopaceus." Proceedings of the Zoological Society of London 1876, 275-277. https://doi.org/10.1111/j.1096-3642.1876.tb02564.x.

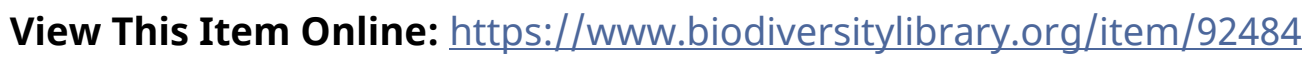

DOI: https://doi.org/10.1111/j.1096-3642.1876.tb02564.x

Permalink: https://www.biodiversitylibrary.org/partpdf/73584

\section{Holding Institution}

Smithsonian Libraries

\section{Sponsored by}

Smithsonian

\section{Copyright \& Reuse}

Copyright Status: Public domain. The BHL considers that this work is no longer under copyright protection.

This document was created from content at the Biodiversity Heritage Library, the world's largest open access digital library for biodiversity literature and archives. Visit BHL at https://www.biodiversitylibrary.org. 